\title{
Analiza pseudodogađaja u strateškom komuniciranju visokog školstva u Hrvatskoj
}

\author{
Lucijano Jakšić* \\ Krešimir Dabo** \\ Marija Volarević****
}

\section{SAŽETAK}

Komunikacija s ciljanom javnosti i promocija proizvoda i usluga proteklih godina transformirala se iz mogućnosti u nužnost, a odnosi se na profitni i neprofitni sektor gospodarstva. Digitalizacija i popularizacija društvenih medija, potreba za publicitetom i dosegom do krajnjih korisnika i potrošača te praćenje konkurencije postaju primarni izazovi strateškog komuniciranja. Isticanje pojedinih elemenata poslovanja na nov i inovativan način omogućava privlačenje pažnje javnosti te postizanje šireg publiciteta. U tome se posebno ističe alat odnosa s javnošću tzv. promidžbena dosjetka, pseudodogađaj ili PR stunt. Novi mediji, a posebno platforme za društveno umrežavanje, ovakvim sadržajima daju veliki doseg, značajnu popularnost, ali možda ono najvažnije - veliki povrat uloženog. Ovakav trend ne zaobilazi ni visoko obrazovanje. Preglednim istraživanjem ustanovljeno je da se elementi pseudodgađaja već koriste u komunikaciji svjetski poznatih visokoobrazovnih sustava, a svi se baziraju na kolektivnim i timskim aktivnostima te zajedničkom stvaranju sadržaja koji se dijeli $i$ postaje dio medijskog izvještavanja. Cilj je ovog rada ispitati percepciju javnosti vezanu uz odabrane pseudodogađaje u hrvatskome privatnom visokom obrazovanju. Istraživanje se temelji na uzorku ciljanih javnosti privatnih visokih učilišta u Hrvatskoj te ispitivanju percepcije sadržaja i poruka pseudodgađaja

\footnotetext{
* Dr. sc. Lucijano Jakšić, predavač na Europskoj poslovnoj školi Zagreb, e-mail: lucijano.jaksic@ebus.hr.

** Dr. sc. Krešimir Dabo, viši predavač na Edward Bernays University College, e-mail: kresimir.dabo@bernays.hr.

*** Marija Volarević, predavač na Sveučilištu VERN', e-mail: marija.volarevic@vern.hr.
} 
kojima se promoviraju visoka učilišta. U radu je primijenjen dvostruki metodološki pristup kako bi se ostvario postavljeni cilj. Metodom analize sadržaja ispitan je javno dostupan medijski sadržaj o odabranim privatnim visokim učilištima te su doneseni zaključci o fokusu medijske objave, vrijednosnoj orijentaciji prema pseudodogađaju te prema visokom učilištu. Metodom $Q$ ispitana je percepcija ciljanih javnosti vezano uz promotivne aktivnosti visokog školstva u Hrvatskoj, konkretno odabranih pseudodogađaja na njihovome visokom učilištu. Privatno visoko školstvo u Hrvatskoj karakterizira visoka konkurentnost. S time je povezana i potreba za odabirom odgovarajućih komunikacijskih aktivnosti. Doprinos je ovog rada i u eksplorativnom pristupu fenomenu pseudodogađaja u visokom obrazovanju u Hrvatskoj te detektiranju promotivnih elemenata odabranih visokoobrazovnih institucija.

Ključne riječi: odnosi s javnošću, promocija, pseudodogađaj, strateška komunikacija, visoko obrazovanje

\section{Uvod}

Strateško komuniciranje privatnoga visokog školstva u Hrvatskoj s ciljem promocije, jačanja vidljivosti i pozicioniranja na tržištu razvija se intenzivno posljednjih nekoliko godina. $\mathrm{U}$ takvom procesu različite privatne ustanove koriste i različite metode. Mnoge od njih mogu se svrstati u uobičajene marketinške alate ili alate odnosa s javnošću. Međutim, sukladno galopirajućem razvoju komunikacijske i marketinške industrije, primjetni su i novi trendovi i korištenje novih pristupa u strateškom oblikovanju poruka privatnih visokoškolskih učilišta prema njihovima ciljanim javnostima. Jedan je od novijih alata u odnosima s javnošću u sektoru visokog obrazovanja u Hrvatskoj pseudodogađaj ili $P R$ stunt, koji može biti od iznimne koristi u kreiranju pozitivnog imidža i stvaranju dobre slike. Prema Suggetu (2019) pseudodogađaj se može definirati kao pažljivo planiran događaj s ciljem skretanja pozornosti javnosti na organizatore ili na neke druge namjere pseudodogađaja. Autor ističe kako razlozi za korištenje takvog alata u odnosima s javnošću leže u velikom potencijalu za povrat ulaganja koje nije veliko, a može ostvariti značajan publicitet. Uz medije, širenju vijesti o pseudodogađaju značajno doprinosi i javnost koja prisustvuje takvom događaju, bilježi ga svojima mobilnim telefonima i dijeli na društvenim platformama. Prema Edwardu Bernaysu, pioniru odnosa s javnošću, pojava odnosa s javnošću seže na sam početak ljudske povijesti, odnosno na odnose između vođa i njihovih sljedbenika. Moć, autoritet i društvena kontrola postoje mnogo dulje u najranijim povijesnim zapisima, a tri elementa odnosa s javnošću stara su koliko i ljudsko društvo: informiranje, uvjeravanje i integriranje ljudi 
Analiza pseudodogađaja u strateškom komuniciranju visokog školstva u Hrvatskoj

(Bernays, 1952: 3). Za pretpostaviti je da su prva primitivna ljudska društva uspješno kontrolirala zajednicu silom, prijetnjama, uvjeravanjem, magičnim i percipiranim natprirodnim ritualima, dok su s pojavom despotizma poput Sumera, Babilona, Asirije, Perzije, Egipta i drugih, gradila ugled i važnost vladara. Pisani i umjetnički izvori iz tog vremena govore o junaštvu vladara u bitkama i pohodima te osvajanju prostranosti tada poznatog i nepoznatog svijeta. Osobnost i politički publicitet tadašnjih vladara vidljivi su i nakon pet tisuća godina. Važnost individualizma i mišljenja vladara dolazi do izražaja pojavom helenske civilizacije, demokratskog društva i procvatom trgovine uslijed pojave kovanog novca (Bernays, 1952: 3). Ovaj Bernaysov kratki povijesni ogled svjedoči o galopirajućem razvoju komunikacijskih znanosti, kao i njihov odraz u praksi tijekom povijesti pa sve do danas. Također, alati i tehnike odnosa s javnošću kontinuirano se razvijaju, a trendove u marketinškom komuniciranju nastoje pratiti i privatne visokoškolske ustanove u Hrvatskoj. Pseudodogađaj samo je jedan od alata suvremenih odnosa s javnošću koji polako pronalazi svoje mjesto u integriranoj komunikaciji privatnih visokih škola, veleučilišta i sveučilišta.

\section{Pozicioniranje privatnih visokih učilišta}

Zahtjevnost tržišta privatnoga visokog obrazovanja nameće obavezu pažljivo kreirane strateške komunikacije s ciljanom publikom. Prema Renko (2009: 12), pozicioniranje predstavlja način na koji osoba ili grupa percipira instituciju u odnosu na druge institucije. Autorica pozicioniranje definira kao čin dizajniranja ponude jedne institucije tako da ona zauzima značajnu i jasno definiranu poziciju u svijesti ciljnog korisnika usluge. Pozicioniranje je u osnovi čin kojim se povezuju proizvodi ili usluge s rješenjima koje kupci traže i osiguravaju im se koristi koje očekuju, dodatno tumači Renko. Dodaje kako izbor strategije pozicioniranja omogućava jedinstven koncept za ulogu u strategiji svakog instrumenta marketinškog miksa te kako nastoji uskladiti sposobnost institucije s potrebama ciljnog tržišta. Potrebno je povezati elemente marketinškog miksa na način da dobivena kombinacija najbolje odgovara ciljnom tržištu, pojašnjava autorica. Razvijanje strategije pozicioniranja, prema Renko, sastoji se od četiriju konkretnih koraka: procjena aktuale pozicije institucije na relevantnom tržištu, izbor željene pozicije, planiranje strategije kako bi se ostvarila željena pozicija te implementacija strategije. U posljednje vrijeme velika pozornost posvećuje se načinu kreiranja i isporuke vrijednosti, a sve radi uspješnijeg pozicioniranja visokoobrazovnih institucija. Visokoobrazovne institucije koje su globalno pozicionirane imaju značajne mogućnosti konkuriranja, kombinirajući prednosti u troškovima s diferenciranjem. Institucije koje kombiniraju dvije strategijske opcije u stanju su se bolje pozicionirati u odnosu na konkurenciju i brže se prilagoditi promjenama u sredini te proširiti svoju kompetentnost (Renko, 2009: 
17). Visokoobrazovne institucije pružaju podršku i analizu te daju smjernice svojim studentima za budući rast i razvoj. U tom kontekstu one čine sve važniju ulogu kao ključni akteri u inovacijama i razvoju regije. Veliki je izazov uskladiti obrazovanje $\mathrm{s}$ brzim društvenim promjenama koje podrazumijevaju intenzivnu mobilnost, migracije stanovništva, informacijsko društvo i visoku tehnologiju. Važnost obrazovanja ljudskih potencijala nikad nije bila važnija jer se u njemu ogleda napredak i samoispunjenje modernog čovječanstva (Vidulin-Orbanić, 2007: 57-71). Globalizacija i njezini procesi zahtijevaju sasvim drugačiji pristup obrazovanju koje ima ulogu oblikovati funkcioniranje pojedinca i društva, stoga o razini i kvaliteti obrazovanja ovisi njihov razvoj i napredak. Obrazovanje u tim uvjetima zahtijeva pripremu ljudskih potencijala za praćenje i prilagodbu društvenim, ekonomskim i kulturnim promjenama (Babiarz i Kukla, 2012: 328-332). Obrazovanje doprinosi jačanju kapaciteta svakog pojedinca da ulaže svoje napore u stjecanje viših vrijednosti i u osobnom i u profesionalnom smislu. Obrazovani pojedinci sposobni su za svjesni i informirani odnos prema osobnim i poslovnim izazovima. Radna se sposobnost, a time i konkurentnost na tržištu rada, povećava. Zaposleni pojedinci obrazovanjem stječu imovinu koja nikad ne zastarijeva i ima najveću vrijednost u današnje vrijeme (Rupčić, 2011: 22). Ono što treba naglasiti jest da visoko obrazovanje poprima sve više karakteristike poslovnog sektora i da je jedan od osnovnih ciljeva stjecanje profita. Tako se sve više posvećuje pozornost uvođenju svih marketinških alata u promociju visokoškolske ustanove jer se privatne visokoškolske ustanove u Republici Hrvatskoj i okružju financiraju prije svega školarinom studenata. Visokoobrazovna institucija svoj imidž i konkurentsku prednost stječe kvalitetnom nastavom, predavačima i zahtjevima studenata jer prati zahtjeve svojih zaposlenika, korisnika i tržišta generalno. Kontinuiranim unaprjeđenjem i razvojem u izvedbi visokih učilišta osigurava svoju željenu pozicioniranost, koja iznimno ovisi i o segmentaciji tržišta. Ako se na visokoškolske institucije gleda kao na poduzeće, a na studente kao na potrošače, istraživanje Marjanovića i Učete (2021: 167) ukazuje koji profil studenata traži koje vrste koristi za određeni smjer/ustanovu. Na temelju njihova istraživanja, visokoškolsko tržište sadrži sedam segmenata, od kojih studenti od studija najviše traže materijalnu i profesionalnu korist, osobnu korist i društvenu korist, a u nešto manjoj količini i institucijsku korist. Autori pojašnjavaju kako se materijalne i profesionalne koristi najviše traže, što upućuje da svi koji upisuju visokoškolsko obrazovanje žele bolji životni standard i karijerni razvoj te bolje plaćena radna mjesta. Nastavno na nužnost razumijevanja i segmentacije tržišta, Miletić (2020: 274) tumači kako se primjena marketinga u odgoju i obrazovanju temelji na neprijepornoj činjenici da odgojno-obrazovne ustanove imaju svoje tržište i svoje potrošače kojima su namijenili svoju intelektualnu uslugu, odnosno znanje koje učenici i studenti, kao potrošači, usvajaju tijekom svojeg školovanja i studiranja. Iz toga proizlazi, tumači autor, da je osnovna uloga marketinga u obrazovanju osmišljavanje 
Analiza pseudodogađaja u strateškom komuniciranju visokog školstva u Hrvatskoj

usluga, točnije procesa usvajanja znanja, na način koji će optimalno zadovoljavati njihove intelektualne potrebe, a samim time i potrebe društva u cjelini. Autor također ističe kako odgojno-obrazovne usluge imaju sve karakteristike svake druge usluge (neopipljivost, nedjeljivost, promjenjivost i prolaznost), ali zbog obilježja te djelatnosti, marketing u obrazovanju ima i neke svoje posebnosti koje svakako treba uvažavati kako bi se mogli očuvati tradicionalni odnosi u odgoju i obrazovanju. Troškovi primjene marketinške koncepcije, naglašava autor, moraju biti manji od koristi koju ta primjena donosi, tako da je svaki strah od rasipanja novca za marketing u obrazovanju neutemeljen. Nadalje, Stanišić, Puška i Maksimović (2015: 3756) tumače kako se širok spektar promjena u području visokog obrazovanja, a koje su se dominantno manifestirale $u$ implementaciji bolonjskog procesa i osnivanju privatnih visokih učilišta, uvukao u visokoobrazovni sustav na tržište, koje po svojim karakteristikama sve više aludira na tržište osobne potrošnje. Autori pojašnjavaju kako se u centru pažnje nalazi student, a što je ekvivalent potrošaču u marketinškom konceptu. Prethodno je impliciralo intenziviranje primjene promotivnih strategija na visoka učilišta, pojašnjavaju autori, a što je u skladu s trendovima u poslovanju organizacija ovog tipa u svijetu. Autori zaključuju kako upravo ti novi trendovi poslovanja nameću potrebu trajnog provođenja komunikacijskih aktivnosti visokih učilišta, bez obzira na to jesu li njihovi osnivači država ili privatni sektor.

\section{Specifičnosti privatnoga visokog obrazovanja u Hrvatskoj}

Propulzivni sektor privatnoga visokog obrazovanja u Hrvatskoj svoju je ekspanziju doživio posljednjih nekoliko godina. Sukladno Agenciji za znanost i visoko obrazovanje visoka učilišta u Republici Hrvatskoj (Azvo.hr, 2021) podrazumijevaju sveučilišta (sa svojim sastavnicama - fakultetima i umjetničkim akademijama), veleučilišta i visoke škole. Agencija ističe kako je sveučilište ustanova koja organizira i izvodi sveučilišne studije, a može organizirati i izvoditi i stručne studije, dok su veleučilišta i visoke škole ustanove koje organiziraju i izvode stručne studije. Nadalje, na internetskoj stranici Agencije napominje se kako u Republici Hrvatskoj trenutno djeluje 119 visokih učilišta sa statusom ustanove: 8 javnih sveučilišta, 2 privatna sveučilišta, 68 fakulteta i umjetničkih akademija te 1 sveučilišni centar na javnim sveučilištima, 4 privatna veleučilišta, 11 javnih veleučilišta, 22 privatne visoke škole i 3 javne visoke škole (Azvo.hr, 2021). Te brojke svjedoče o značajnoj količini privatnih visokoobrazovnih ustanova. Pokretanjem različitih privatnih visokih škola, veleučilišta i sveučilišta, otvorio se i prostor za novi vid marketinške komunikacije s potencijalnim ciljanim javnostima poput budućih studenata, njihovih roditelja, ali i svih onih koji žele studirati uz rad. Paralelno s rastom privatnih visokoškolskih ustanova nametnula se potreba osmišljavanja strateškog komuniciranja kako bi se stvorila konkurentska diverzifikacija i tržišna pozicija. Također, 
iznimno je važno promatrati visoko obrazovanje kao značajan društveni, ekonomski i znanstveni pojam s obzirom na to da visoko obrazovanje, između ostalog, pruža oslonac unaprjeđenju društva te sveukupnom kvalitetnijem standardu života. Prema Strategiji obrazovanja, znanosti i tehnologije, Hrvatski sabor donosi kako Hrvatska prepoznaje obrazovanje i znanost kao svoje razvojne prioritete koji joj jedini mogu donijeti dugoročnu društvenu stabilnost, ekonomski napredak i osiguranje kulturnog identiteta (Vlada Republike Hrvatske). Prema Jongbloedu i suradnicima (2008: 323-354) u suvremenim društvima mnoge organizacije i pojedinci imaju udio u visokom obrazovanju i žele aktivno sudjelovati u formiranju obrazovne politike. U tom smislu, institucije postaju sve više dio društva. Posljedica je da su visokoškolske institucije i nacionalne vlade suočene s velikim očekivanjima i znanje tretiraju izvorom svih rješenja. To je dovelo do pojave novih stručnjaka, novih studijskih programa, usluga i administrativnih jedinica organizacije, a sve $\mathrm{s}$ ciljem da se odgovori na izazove (Jongbloed i sur., 2008: 323-354). Također, važno je naglasiti kako je obrazovanje u 21. stoljeću usmjereno prema stjecanju novih, kreativnih i prilagođenih znanja i vještina, prilagođavajući se tržištu rada te samom okružju. Zemlje čija se razvojna politika i djelovanje ne temelje na konceptu doživotnog učenja i razvoja osuđene su na političku i ekonomsku propast. Ulaganje u obrazovanje, obuku te razvoj pojedinca, a i samog društva, trebalo bi odgovarati brzini tehnoloških promjena i razvoja. Demografske promjene posebno su važne u marketinškim istraživanjima. Utjecaj demografskih promjena najviše je vidljiv kroz promjene u strukturi stanovništva uz istovremeno produženje životnog vijeka, što za posljedicu ima povećanje potražnje za obrazovnim, turističkim, rekreacijskim i zdravstvenim uslugama. S druge strane, Gajić navodi da sve manji broj mlađeg stanovništva utječe na neravnotežu na tržištu rada, ali i na potražnju za uslugama obrazovanja (Gajić, 2010: 34). Kako Wertheimer-Baletić (2017: 1-28) donosi, Hrvatska nakon 1990. godine pokazuje nekoliko specifičnih značajki. To je najprije negativna ukupna demografska bilanca jer ima ukupnu depopulaciju, odnosno njezin se agregatni kvantitativni rezultat iskazuje u smanjivanju ukupnog broja stanovništva. Drugo, Hrvatska istovremeno bilježi i prirodnu depopulaciju uvjetovanu većim brojem umrlih osoba u odnosu na broj živorođene djece (negativnu prirodnu promjenu, prirodno smanjenje stanovništva) koja, uz ostale nepromijenjene uvjete i uz uvjet da traje dovoljno dugo (a u Hrvatskoj traje već dva i pol desetljeća), označava izumiranje, tj. nestajanje stanovništva. Treće, Hrvatska istovremeno bilježi i negativan migracijski saldo koji je uvjetovan većim brojem iseljenih osoba u odnosu na broj doseljenih i indikator je niske razine ekonomskog razvoja u odnosu na razmatrane zapadnoeuropske zemlje (Wertheimer-Baletić, 2017: 1-28). S gledišta pojedinca, računica o koristima obrazovanja nešto je jednostavnija nego s gledišta društva. Bolje obrazovane osobe imaju više nadnice od drugih osoba sličnih karakteristika, ali slabijeg obrazovanja te češće i dulje sudjeluju na tržištu rada. Veće su- 
Analiza pseudodogađaja u strateškom komuniciranju visokog školstva u Hrvatskoj

djelovanje na tržištu rada i veća zaposlenost dijelom proizlaze i iz viših oportunističkih troškova nesudjelovanja na tržištu rada, odnosno viših nadnica s kojima se na tržištu suočavaju bolje obrazovane osobe. No, neovisno o višem stupnju sudjelovanja, bolje obrazovani pojedinci lakše pronalaze posao te ih karakterizira manji rizik pada u nezaposlenost. Kao donekle specifičan slučaj vjerojatno se izdvaja samo Italija. U Italiji su studenti nakon diplome u prosjeku tražili posao i po 19 mjeseci, što je tek neznatno niže od prosjeka za osobe sa srednjoškolskim obrazovanjem (20 mjeseci). Također, rizik nezaposlenosti za osobe s fakultetskim obrazovanjem sve do njihove 35. godine jednak je riziku nezaposlenosti za osobe sa srednjom ili osnovnom školom. U skladu s time, bolje obrazovani pojedinci izloženi su i značajno nižem riziku siromaštva. Dok su osobe s osnovnim obrazovanjem na razini prosjeka Europske unije 2000. godine bile izložene riziku siromaštva uz vjerojatnost od $19 \%$, oni s visokim obrazovanjem imali su tek $7 \%$ vjerojatnosti pada u siromaštvo (Babić i sur., 2006: 25-65). Teško je predvidjeti koji će poslovi, znanja i vještine biti potrebni u sljedećih 10 godina, no s potrebom za razvojem tehnologije razvija se i društvo. Potrebe za znanjem rastu te suvremene poslovne aktivnosti zahtijevaju poznavanje moderne tehnologije.

\section{Strateško komuniciranje u visokom školstvu}

Mnoge organizacije ne razvijaju niti provode komunikacijsku strategiju, tvrdi Steyn (2003: 168-183). U određenoj se mjeri u praksi susreće razvoj strategije brenda, strategije oglašavanja i nekih oblika integrirane marketinške komunikacije. Postoji vrlo malo primjera vođene komunikacijske strategije na korporativnoj razini ili primjera kad strateg (komunikator) praktičar uspije postići kvalitativni utjecaj na formuliranje strategije na najvišoj razini korporativnog upravljanja (Steyn, 2003: 168183). Strateški pristup komunikaciji podrazumijeva integrirani pristup na nekoliko razina, gdje svaka komunikacijska funkcija ispunjava određene ciljeve, usmjerena je na prioritete koji se planiraju za postizanje ciljeva i uključuje odabir najučinkovitijih komunikacijskih kanala. Da bi se postigao puni strateški učinak, sva realizirana komunikacija i svi komunikacijski kanali moraju biti prilagođeni postizanju cilja i međusobno usklađeni i s korporativnom strategijom (Argenti, Howell i Beck, 2005: 83-89). Odnosi s javnošću, a time i pseudodogađaji, u velikoj su mjeri isprepleteni sa strateškom komunikacijom. Oba imaju za cilj razviti organizaciju kroz uspješnu komunikaciju i zahtijevaju snažnu usmenu i pismenu komunikaciju, međuljudske vještine i rad u multidisciplinarnim timovima (Sveučilište Marywille, n.p.). Teoretski, važnost pseudodogađaja može se prepoznati u gotovo svim elementima strateškog pristupa komunikaciji. Ako pseudodogađaj u praksi postigne ili premaši planirani publicitet, može dobiti buduću važnost u strateškoj komunikaciji. Analizirati okolinu i definirati temeljne strateške ciljeve iznimno je važno za svako veleučilište 
i visoku školu. Međutim, neizostavno je formulirati i interpretirati strategiju, odnosno odrediti stratešku orijentaciju svakoga takvog visokog učilišta. Formuliranje strategije proces je razvoja dugoročnih planova za efektivno upravljanje prilikama i prijetnjama iz okoline s obzirom na snage i slabosti poslovnog subjekta (Buble i dr., 2005: 10). Svaki poslovni subjekt treba razmatrati tri vrste strategije: korporacijsku, poslovnu i funkcijsku strategiju. S druge strane, Dubravka Krivačić (2010: 121131) tumači kako u današnje vrijeme, poslovnu strategiju, kao i sve druge postavke suvremenog menadžmenta, trebaju formulirati i implementirati i poslovni subjekti u industriji obrazovanja. Međutim, autorica postavlja pitanje je li menadžersko razmišljanje namijenjeno samo gospodarskim subjektima, čiji je temeljni cilj profitabilnost te zaključuje kako nije jer su načela, metode i strategije suvremenog menadžmenta nužni i primjenjivi i u poslovnim subjektima u industriji obrazovanja. Primarni cilj tih poslovnih subjekata nije ostvarivanje dobiti, ali jest ostvarivanje kvalitete i konkurentnosti u nemilosrdnom tržišnom okruženju (Krivačić, 2010: 128). Ista autorica napominje kako djelujući u industriji visokog obrazovanja, kad se domaći sustav visokog obrazovanja usklađuje s europskim standardima, sva visoka učilišta nužno su usmjerena na trajni razvoj te izgradnju i održavanje vlastitoga konkurentskog položaja na tržištu. Prema tome, zaključuje, trebaju biti determinirana i nastojanja veleučilišta i visokih škola kako bi postigli značajan položaj u tržišnim segmentima ponude stručnog obrazovanja te održali konkurentsku prednost minimalno u prostornoj regiji gdje su smješteni (Krivačić, 2010: 130).

\section{Pseudodogađaj}

U pokušaju definiranja pseudodogađaja okušali su se mnogi autori. Različite definicije pokušala je sažeti Dubravka Valić Nedeljković (2007: 67-86) pojašnjavajući kako se pseudodogađaji svrsishodno stvaraju samo da bi se osigurao publicitet za vladu, stranku, organizaciju, korporaciju, javnu osobu na svim područjima javnog života. Uz to, autorica smatra kako se često kao sinonim za pseudodogađaj upotrebljava sintagma "medijski događaj" jer se ti događaji i organiziraju samo da bi ih mediji zabilježili. Stoga se uobličuju tako da bi bili medijski atraktivni, tumači Valić Nedjeljković. Istodobno pojašnjava kako novinari moraju ocijeniti istinsku važnost tih događaja za javnost i posvetiti im odgovarajuću, a ne preveliku pozornost. Medijski inicirani događaji oni su koje sami mediji izdvoje i postave na društvenu ljestvicu prioriteta kao iznimno važne za javni interes. Posebno opsežnim novinarskim angažmanom i istraživanjima društvene prakse takvi događaji se s margina društvenog interesa postavljaju u njegovo središte, tumači autorica, te dodaje kako su to uglavnom zbivanja za koja pojedina središta moći ionako ne bi željela da se nađu u medijima. Aktualni događaj u osnovnom pojavnom obliku, primjereno rečenom, bio bi sve ono što se ne može svrstati u dva prethodna tipa. S druge strane, 
Analiza pseudodogađaja u strateškom komuniciranju visokog školstva u Hrvatskoj

Boorstin $(2006: 95,96)$ vrlo konkretno pojašnjava karakteristike pseudodogađaja koji, dizajnirani i kreirani isključivo da privuku medijsku pozornost, moraju imati dva elementa: nedostatak spontanosti (uvijek ih netko planira ili inicira) te se planiraju isključivo da bi novinari o njima izvještavali.

Prema poznatoj njujorškoj agenciji za odnose s javnošću 5W (5wpr.com, 2020), postoje tri glavne kategorije pseudodogađaja koje određuju uspjeh same aktivnosti. To su: uključenost javnosti, pamtljivost i jedinstvenost. Blair Dawson definira karakteristike uspješnog pseudodogađaja (PRweek.com, 2020): 1. izdvaja se na tržištu, 2. cilja novu publiku, 3. pozicionira novu tvrtku na tržištu, 4. djelatnost kompanije stavlja u trend, 5. jača medijski publicitet, 6. povećava društvenu prisutnost. Slično tome, Rich Leigh (Radioactivepr.com, 2018.) potvrđuje četiri ključna elementa dobrog pseudodogađaja: 1. treba biti lako objašnjiv u rečenici, 2. trebao bi se odnositi na proizvod/uslugu koji želi promovirati, 3. trebao bi imati jasne ciljeve, 4. treba biti vizualan.

Pseudodogađaje pojašnjava i Smith (2017: 165-168) navodeći kako je to posebna kategorija interpersonalne komunikacije koja stvara mogućnost za interakciju s ciljanim javnostima. Autor ih dijeli na događaje za građanstvo, sportska događanja, natjecanja, blagdanska događanja, događanja usmjerena na predstavljanje napredovanja tvrtke, povijesno-komemorativni događaji, društvena događanja, kulturnoumjetnička događanja te humanitarna događanja. Smith naglašava kako svako ovakvo događanje mora biti pažljivo osmišljeno, provedeno i financirano te da mora imati dobru i kreativnu promociju. Uz to, autor naglašava kako rezultat manifestacije mora biti jasan i mjerljiv te u svrsi strategije odnosa s javnošću.

\section{Istraživački problem i metodologija}

S ciljem utvrđivanja doprinosa pseudodogođaja većoj vidljivosti visokih učilišta te determiniranja stvaraju li takvi događaji pozitivnu percepciju u javnosti o samoj ustanovi, odabrane su dvije istraživačke metode te su odabrana četiri različita događaja s različitih privatnih visokih učilišta. Prilikom odabira analiziranih primjera, a na temelju teorijske podloge, odabrani su sljedeći kriteriji pseudodogađaja:

1. planirani događaj osmišljen za privlačenje pažnje javnosti na organizatore ili temu (visokog školovanja),

2. cilj događaja je privlačenje pažnje javnosti i podizanje svijesti o konceptu, proizvodu ili usluzi,

3. događaj se organizira profesionalno ili amaterski,

4. događaj ima obilježja vijesti vrijedne objavljivanja, 
5. događaj je neobičan, izniman, zahtjevan u izvedbi, traži odvažnost, vješto je izveden,

6. organizator iniciranjem i upravljanjem tijekom događaja zadržava u većoj ili manjoj mjeri kontrolu nad sadržajem objava u medijima (snimke, konferencija za medije i drugo) (Sugget, 2019).

\section{Analiza sadržaja medijskih objava}

Prva metoda korištena u radu je kvantitativna, ali i kvalitativna analiza s gledišta sadržaja, gdje je istraživač u prvom redu zainteresiran za karakteristike sadržaja poruke (Halmi, 1996: 283). Metoda analize sadržaja česta je metoda ispitivanja medijskog teksta i kako Elezović (2012: 61-88) objašnjava, to je način kojim se nastoji proizvesti objektivan, kvantitativan i opravdan opis sadržaja. Točnije, praćenjem sadržaja pokušavaju se proizvesti odgovarajuće veze i odnosi između pojava u podacima, pojašnjava autor. No, u kontekstu analize sadržaja važni su kvalitativni i kvantitativni aspekti analize sadržaja, osobito kad je broj analiziranih jedinica premalen za primjenu statističkih metoda (Poljičak, 2014: 8). Upravo zbog malog broja medijskih članaka o pseudodogađajima, odnosno promotivnim dosjetkama visokoobrazovnih institucija, kvantitativna analiza sadržaja pokazala se kao prikladna metoda za ispitivanje fokusa medijskih objava te kontekst spominjanja i pseudodogađaja i visokoobrazovne institucije.

Kao jedinica analize uzet je jedan članak o pseudodogađaju objavljen na mrežnom portalu. Do uzorka analize došlo se pretraživanjem odabranih pseudodogađaja na tražilici te izdvajanjem medijskih objava koje se odnose na pseudodogađaj koji organizira odabrana visokoobrazovna institucija. U istraživanje su uključene četiri privatne visokoobrazovne institucije: Zagrebačka škola ekonomije i managementa, Sveučilište VERN', Europska poslovna škola Zagreb i Edward Bernays University College. Odabrane visokoobrazovne institucije izdvojene su upravo zbog istaknutosti svojih događanja te čine dio preliminarnog istraživanja ispitivanja pseudodogađaja u visokom obrazovanju. Tako je ukupan uzorak za analizu sadržaja činilo 20 digitalnih medijskih objava koje su se odnosile na pseudodogađaj odabranih visokoobrazovnih institucija. Omjer broja izdvojenih medijskih objava prema pseudodogađaju određene visokoobrazovne institucije prikazan je u tablici 1 .

Cilj ovog dijela istraživanja bio je ispitati način medijskog izvještavanja o pseudodogađaju te utvrditi korelaciju između promidžbene dosjetke i visokoobrazovne institucije.

Na temelju metodologije i cilja istraživanja postavljena su sljedeći istraživački ciljevi vezani za ovaj dio istraživanja: 
Analiza pseudodogađaja u strateškom komuniciranju visokog školstva u Hrvatskoj

Tablica 1: Omjer broja izdvojenih medijskih objava prema pseudodogađaju određene visokoobrazovne institucije

Table 1: Ratio of the number of isolated media publications according to the pseudo-event of a certain higher education institution

\begin{tabular}{|l|l|l|}
\hline $\begin{array}{l}\text { VISOKOOBRAZOVNA } \\
\text { INSTITUCIJA }\end{array}$ & PSEUDODOGAĐAJ & $\begin{array}{l}\text { BROJ MEDIJSKIH } \\
\text { OBJAVA }\end{array}$ \\
\hline $\begin{array}{l}\text { Zagrebačka škola ekonomije } \\
\text { i managementa }\end{array}$ & $\begin{array}{l}\text { Studentska konferencija } \\
\text { Management informacijskih } \\
\text { sustava }\end{array}$ & 2 \\
\hline Sveučilište VERN' & $\begin{array}{l}\text { The Galerija - virtualna } \\
\text { izložba studenata }\end{array}$ & 8 \\
\hline Europska poslovna škola Zagreb & Smotra studentskih poduzeća & 5 \\
\hline $\begin{array}{l}\text { Edward Bernays University } \\
\text { College }\end{array}$ & PRaznici na Bernaysu & 5 \\
\hline
\end{tabular}

Izvor: izrada autora prema rezultatima pretraživanja digitalnih medija

IC1: Utvrditi fokus i način medijskog izvještavanja o pseudodogađaju.

IC2: Ispitati vrijednosnu orijentaciju medijskog članka prema pseudodogađaju i prema visokoobrazovnoj instituciji.

\section{Istraživanje percepcije prema Q-metodologiji}

Druga metoda primijenjenog istraživanja je Q-metodologija. Upotrijebljena je za analizu sadržaja zbog svoje opravdanosti kao abduktivnog pristupa za donošenje zaključaka - zaključivanje bazirano na najvjerojatnijem objašnjenju promatranog problema koje proizlazi iz faktorske analize prikupljenih podataka (Betterevaluation.org, 2020). Klasično induktivno zaključivanje donosi korist kod razrješavanja problema gdje značenja empirijskih problema nisu problematična, dok za razliku od prethodnog Q-metodologija ima za cilj ponuditi sofisticiraniju razinu smislenog razumijevanja nekog problema (Shank, 1998: 8). Q-metodologija prepoznatljiva je po tome da ispitanici prema subjektivnom dojmu rangiraju ponuđene kartice s izjavama u piramidu oblika ,kvazi-prirodne raspodjele“. Broj mjesta u ,piramidi““ odgovara broju kartica i horizontalno se proteže od u praksi normalnih $-6 /+6$ do uskih -3/+3 (Rogers, 2011: 158). Ispitanik prema subjektivnom dojmu raspodjeljuje kartice u negativne, neutralne ili pozitivne, ali s ograničenjem broja kartica po svakoj kategoriji i visini ocjene u intervalu od -3 do +3 . Ovom metodom željelo se doznati koji tip ili tematski smjer i izvedba pseudodogađaja može u najvećoj mjeri osigurati prijenos željenih poruka. Prijenos poruke uvelike ovisi o njezinoj prilagođenosti primatelju odnosno njegovu/njezinom subjektivnom dojmu te je znanstveno uteme- 
ljena analiza subjektivnog dojma o nekom problemu ili temi primarno područje primjene Q-metodologije.

Jedinica analize stoga glasi: Koji od sljedećih događaja Vama najbolje komunicira tradiciju, kvalitetu i garanciju stečenih znanja nekoga visokog učilišta u Hrvatskoj?

Za formuliranje dovoljnog broja kartica s ponuđenim događajima i njihovim alternativama za potrebe ovog istraživanja formirano je i testirano 26 izjava. Kako bi se postigao prihvatljiv broj alternativa odnosno spektra tematskih smjerova i izvedbi za prijenos željenih poruka i koje je stoga potrebno razabrati i rangirati (IP1: Koji tip ili tematski smjer i izvedba pseudodogađaja osiguravaju prijenos željenih poruka?), ponuđene su varijante događaja uživo i online. Kartice su ispitanicima diseminirane u papirnatom obliku zbog obima teksta opisa iako za istu namjenu postoje specijalizirani računalni programi (Q Methodology). Analiza sadržaja provedena je faktorskom analizom u programu KenQ Analysis verzija 1.0.6 (Banasick, Shawnbanasick.github.io, 2019).

Uzorak ispitanika kod primjene Q-metodologije ne igra presudnu ulogu jer je u praksi primijećeno da faktor kompozitne pouzdanosti (eng. composite reliability) za npr. 170 ispitanika iznosi 0,9985, dok se statistički prihvatljiv faktor 0,9524 u uobičajenim okolnostima postiže i s manje od 35 ispitanika (Brown, 1980: 191, 192 prema: Marshall, 2003: 109). Iz populacije osnovnog skupa šire javnosti nepoznate veličine u Hrvatskoj izuzet je stratificirani uzorak od 40 ispitanika prema sljedećim svojstvima osnovnog skupa: minimalna razina tekućeg obrazovanja (srednje) te svakodnevna izloženost sredstvima informiranja (radio, televizija, internet). Uzorkovanje je realizirano tehnikom ,snježne grude“ što pretpostavlja odabir uskog kruga ispitanika potrebnih svojstava koji su dobrovoljnom preporukom širili uzorak na druge relevantne osobe (Milas, 2005: 413). Uzorak je od manjeg broja proširen do planiranog obujma od 40 ispitanika. Planirano je da uzorak bude izbalansiran jednakim brojem ispitanika svake spolne i obrazovne skupine, no na terenu se događalo odustajanje ispitanika koje je rezultiralo različitim udjelima ispitanika prema spolnim karakteristikama (muško: 17, žensko: 23) te prema obrazovnim karakteristikama (srednja škola u tijeku: 12, preddiplomska razina: 6, diplomska razina: 17 , magistar/doktor znanosti: 5). Prema dodatnim pitanjima, uz samu Q-metodologiju, prikupljeni su i drugi podaci o ispitanicima. O dodatnom školovanju razmišlja $65 \%$ ispitanika. Da kvalitetnije obrazovanje nude državna visoka učilišta smatra 47,5 \% ispitanika, a da je kvaliteta studiranja podjednaka na državnim i privatnim visokim učilištima smatra 27,5 \% ispitanika. Tvrdnju da državna visoka učilišta nude znanje koje traže poslodavci smatra 55 \% ispitanika, a da je znanje dobiveno na privatnim i državnim visokim učilištima za potrebe poslodavca podjednako smatra 42,5 \%. Za $62,5 \%$ ispitanika, posljedice koronakrize ostavile su negativan trag, a tek 12,5\% osjetilo je pozitivnu promjenu uslijed okolnosti pandemije bolesti COVID-19. Za 
Analiza pseudodogađaja u strateškom komuniciranju visokog školstva u Hrvatskoj

$95 \%$ ispitanika preferirani način poslovnog susreta u grupi 2-10 osoba prije pandemije bio je uživo, dok je sad to preferirano samo za $50 \%$. Uz to, $80 \%$ ispitanika svoje vještine komuniciranja putem računalnih alata za komunikaciju i grupni rad ocjenjuje ocjenom 4 ili 5.

Za predmetno istraživanje 40 ispitanika uspješno je testirano i postignut je faktor kompozitne pouzdanosti 0,976 (prosjek za Faktor 1 i Faktor $2(0,992 / 0,960)$ ). Faktorskom analizom dobiveni su sažeti stavovi i razmišljanja grupirani između pojedinih ispitanika i grupa ispitanika, odnosno prirodno grupirani stavovi u obliku faktora. Analizom je izdvojeno osam faktora, a od toga dva imaju veću statističku važnost od ostalih koji su utvrđeni statističkim alatom scree plot (D'agostino i Russell, 2005). Faktori 3-8 nisu opravdani za daljnju analizu jer poprimaju slično odstupanje od x-osi prema svojim svojstvenim vrijednostima (eng. eigenvalues, na mjestu točke prelamanja krivulje Scree plota) te stoga predstavljaju redundanciju.

Faktorskom analizom ustanovljena su već spomenuta dva statistički značajna faktora, Faktor 1 i Faktor 2. Faktori se izdvajaju matematički kao rezultat sličnih odabira i rangiranja (eng. loading) izjava ispitanika. Faktori s većim ,punjenjem“ od veće suvažnosti pri analizi. Interpretacija faktora i donošenje zaključaka ovisi o ,,razlikovnim izjavama“ koje imaju tzv. „stršeće“ pozitivno ili negativno punjenje.

\section{Predstavljanje odabranih primjera}

U svrhu istraživanja odabrana su četiri događaja s četiri različite privatne visokoškolske ustanove, a koji se mogu uklopiti u karakteristike pseudodogađaja sukladno Suggetu (Thebalancecareers.com, 2019), opisana u prethodnom poglavlju.

Studenska konferencija u organizaciji Zagrebačke škole ekonomije i managementa, Management Informacijskih Sustava događaj je koji je okupio vodeće tvrtke u Hrvatskoj u korištenju informacijskih sustava te najbolje studentske projekte na kolegiju Management informacijskih sustava u području uvođenja ERP sustava u odabrane tvrtke. Osnovni je cilj konferencije predstavljanje najboljih studentskih projekata na temu uvođenja ERP sustava u odabrana poduzeća pri kolegiju Management informacijskih sustava. U posljednjih nekoliko desetljeća, pri informatizaciji poslovnih procesa i sustavnim uvođenjemu informacijskih sustava u poslovanje, uz ubrzani razvoj tehnologije dolazi do potrebe za edukacijom na području upravljanja informacijskim sustavima. Osnovni principi, kao i napredni primjeri upravljanja informacijskim sustavima, predstavljeni su na ovoj konferenciji kroz niz gostujućih predavanja stručnjaka iz prakse. (Zsem.hr, 2020)

U organizaciji studenata Sveučilišta VERN' javnosti je predstavljena virtualna izložba fotografija pod nazivom ,theGalerija koncept“" koja se mogla razgledati putem mobitela. Izložba je donijela radove izabranih umjetnika kroz koje je prikazana 
nova perspektiva na svijet izazvana životom u karanteni, a spoj je radova profesionalnih fotografkinja i pobjednika amatera foto natječaja, čime je format fotografije predstavljen kao ulaznica u umjetnost koja je dostupna svakom pojedincu. Umjetnice čiji su radovi izloženi dolaze iz različitih dijelova regije, a njihovi specifični stilovi pridonijeli su stvaranju jedinstvenog doživljaja umjetnosti. One su Stella Mešić, Irma Vargić, Tajana Dedić - Starović te Vida Žagar, koje su svojim radovima prikazale viđenje života u karanteni na posve drugačiji način. Izložba se mogla razgledati do kraja lipnja 2020. na platformi Artsteps, a moguće ju je bilo razgledati putem mobilne aplikacije, posjetom na mrežnu stranicu ili uz VR naočale. Izložba se održavala kao projekt kreativne platforme theGalerija, koju su pokrenuli VERNovi studenti, a iako je prvotno bila planirana u realnom prostoru, ovim su virtualnim iskorakom dali i dodatni poticaj razvoju cijele platforme (Vern.hr, 2020).

Europska poslovna škola Zagreb i BIZ-Poduzetnički inkubator organiziraju Smotru studentskih poduzeća i studentskih poduzetničkih inkubatora. Na smotri sudjeluju i druge visokoškolske ustanove, studentska poduzeća te predstavnici alumni zajednice koji su uspješno pokrenuli poduzeća za vrijeme studija. Europska poslovna škola Zagreb inicijator je uspostave programa „Mreža studentskih poduzetničkih inkubatora“, koji je pokrenut 2012. godine u partnerstvu s Hrvatskom agencijom za malo gospodarstvo i investicije, a stručnjaci Europske poslovne škole Zagreb pokrenuli su projekt studentskih poduzetničkih inkubatora sa stvarnim studentskim poduzećima. Medijski pokrovitelji Smotre 2020. su Suvremena.hr, Poslovni savjetnik, Poslovni FM, portal Women in Adria i dr. (Ebus.hr, 2020).

PRaznici na Bernaysu besplatan su edukativni projekt namijenjen maturantima i studentima preddiplomskih studija. Uz koncept zabave i znanja, PRaznici na Bernaysu sudionicima donose zanimljiva predavanja i radionice o aktualnim temama iz svijeta medija, odnosa s javnošću i turizma. Aktivnim sudjelovanjem u predavanjima i interaktivnim radionicama sudionici PRaznika prikupljaju bodove i konkuriraju za glavnu nagradu - školarinu za jedan od Bernaysovih studija - preddiplomske studije Komunikacijski menadžment ili Menadžment i marketing turističke destinacije te diplomski studij Upravljanje odnosima s javnošću. Sudionici svih predavanja i radionica ostvaruju popust na jednogodišnju školarinu za studij po izboru na Edward Bernays University Collegeu. U protekle četiri godine, koliko se održava projekt, u PRaznicima je sudjelovalo više od 130 srednjoškolaca i studenata završnih godina preddiplomskih studija koji su upoznali studijske programe Bernaysa i učili o važnosti društvenih mreža, održavanju odnosa s influencerima i brendiranju destinacija, kako se predstaviti (medijima), kako probuditi kreativca u sebi te kako glasi priča o uspjehu nekih od najvećih evenata u Hrvatskoj i inozemstvu, o ulozi odnosa s javnošću u izgradnji imidža, o važnosti dobroga javnog nastupa na televiziji, izgradnji i održavanju odnosa s medijima te provođenju kreativnih kampanja na 
Analiza pseudodogađaja u strateškom komuniciranju visokog školstva u Hrvatskoj

društvenim mrežama, kako velike korporacije grade svoj imidž, koji su izazovi u novinarstvu te koje su ključne stvari za pripremu novinarskih vijesti (Bernays.hr, 2020).

\section{Rezultati istraživanja}

\section{Analiza sadržaja}

Analiza sadržaja digitalnih objava o pseudodogađaju odabranih visokoobrazovnih institucija podijeljena je u tri dijela. Prvim dijelom analize sadržaja cilj je bio ispitati općenite informacije o medijskoj objavi. Analiza je pokazala da mediji, kad izvještavaju o pseudodogađaju visokoobrazovnih institucija, pretežno koriste format vijesti (13 analiziranih članaka) ili formatu kratke vijesti (7 analiziranih članaka). Što se tiče grafičke opreme članaka, većina analiziranih članaka (13 analiziranih članaka) objavljena je s fotografijom, dok jedan članak ima kombinaciju videa i fotografije. Zanimljiv je podatak da 6 analiziranih članaka nema grafičku obradu. U obradi vijesti, većina naslova vijesti (13 analiziranih članaka) je informativna, odnosno povezana je sa sadržajem samog članka i otkriva o čemu se u članku radi. Manji broj analiziranih objava imala je senzacionalistički naslov ( 3 analizirana članka) ili izrazito afirmativan naslov (4 analizirana članka) prema pseudodogađaju. U drugom dijelu analize sadržaja cilj je bio ispitati fokus izvještavanja o pseudodogađaju. Analizom je utvrđeno da mediji u izvještavanju o odabranim događanjima pretežno izvještavaju vrijednosno pozitivno (12 analiziranih članaka) o pseudodogađaju. Budući da je riječ o događanju koje za cilj ima promociju visokoobrazovne institucije, nijedan analizirani članak nije negativno izvještavao o pseudodogađaju,

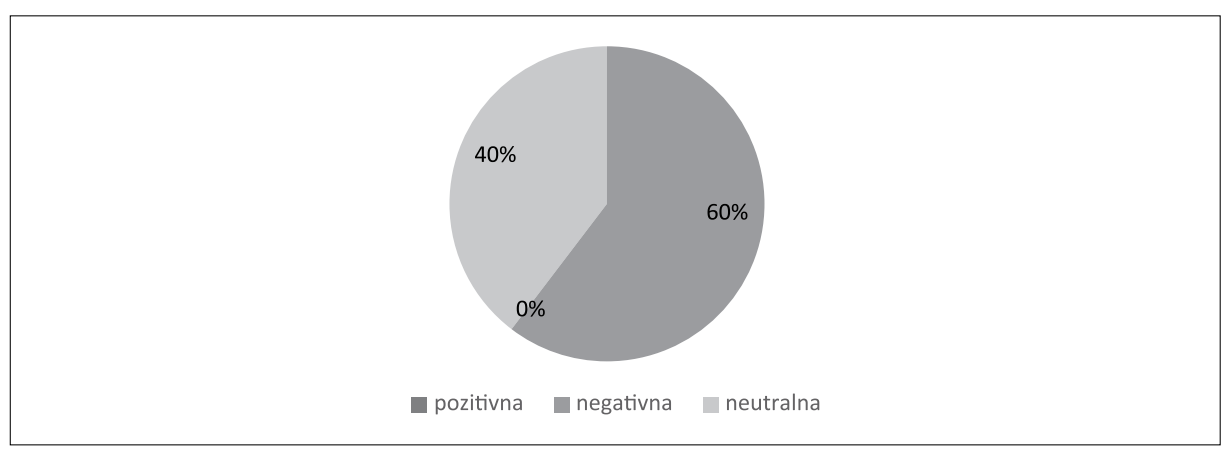

Grafikon 1. Vrijednosna orijentacija članka prema pseudodogađaju Grafikon 1. Value orientation of the article according to the pseudo-event

Izvor: autori rada 
dok je 8 analiziranih članaka objava bilo neutralno i fokus izvještavanja bio je samo na objektivnoj najavi događanja. Omjer vrijednosne orijentacije u izvještavanju prikazan je u grafikonu 1 .

Većina analiziranih objava izvještava o pseudodogađaju kao o događanju (13 analiziranih članaka) pa je tako većina objava ili najava ili izvještaj nakon održanog događanja. Većina objava (12 analiziranih članaka) ističe organizatore pseudodogađaja u izvještavanju. Zanimljivo je kako se u pseudodogađaju Sveučilišta VERN' i Zagrebačke škole ekonomije i managementa kao organizatori događanja navode studenti, dok se kod događanja Europske poslovne škole Zagreb i Edward Bernays University Collegea upravo visokoobrazovne institucije navode kao organizatori i inicijatori događanja. Kad je riječ o kontekstu objava, analiza je pokazala da se u analiziranima medijskim objavama ističe inovativnost događanja (15 analiziranih članaka) te studente (11 analiziranih članaka) ili kao inicijatore ili kao važne čimbenike pseudodogađaja. Iako je pseudodogađaj vezan za visokoobrazovnu instituciju, većina analiziranih objava, čak njih 15 , ne spominje visoko učilište u glavnom fokusu, kao što je i prikazano u grafikonu 2.

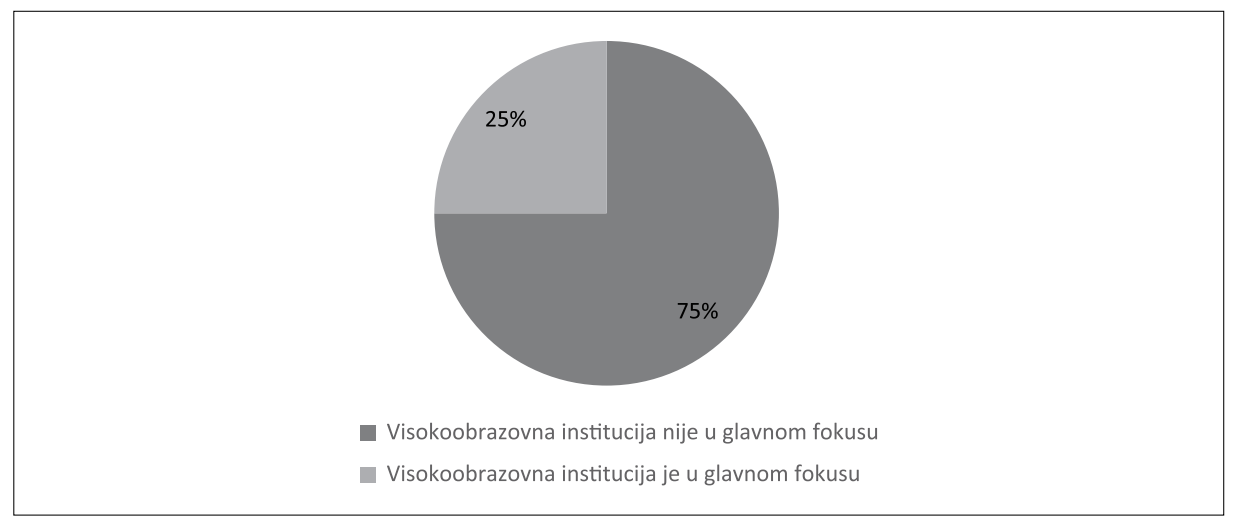

Grafikon 2. Prikaz glavnog fokusa pseudodogađaja u odnosu na visokoobrazovnu instituciju

Graph 2. Overview of the main focus of pseudo-events in relation to the higher education institution

Izvor: autori rada

Treći dio analize sadržaja imao je za cilj ispitati kontekst spominjanja visokoobrazovne institucije u sklopu medijskog izvještavanja o pseudodogađaju. U nijednome analiziranom medijskom članku visokoobrazovna institucija nije bila u glavnom fokusu medijskog izvještavanja, već je to bilo upravo izvještavanje o odabranim 
pseudodogađajima. No, visokoobrazovna institucija u većini analiziranih objava (13 analiziranih članaka) spominje se u kontekstu pseudodgađaja. Analiza je pokazala da kad mediji izvještavaju o visokoobrazovnoj instituciji u kontekstu pseudodogađaja, pretežno izvještavaju u kontekstu inovativnosti događanja (6 analiziranih članaka). Detaljan omjer konteksta u kojem se spominje visokoobrazovna institucija kad se izvještava o pseudodogađaju prikazan je u grafikonu 3.

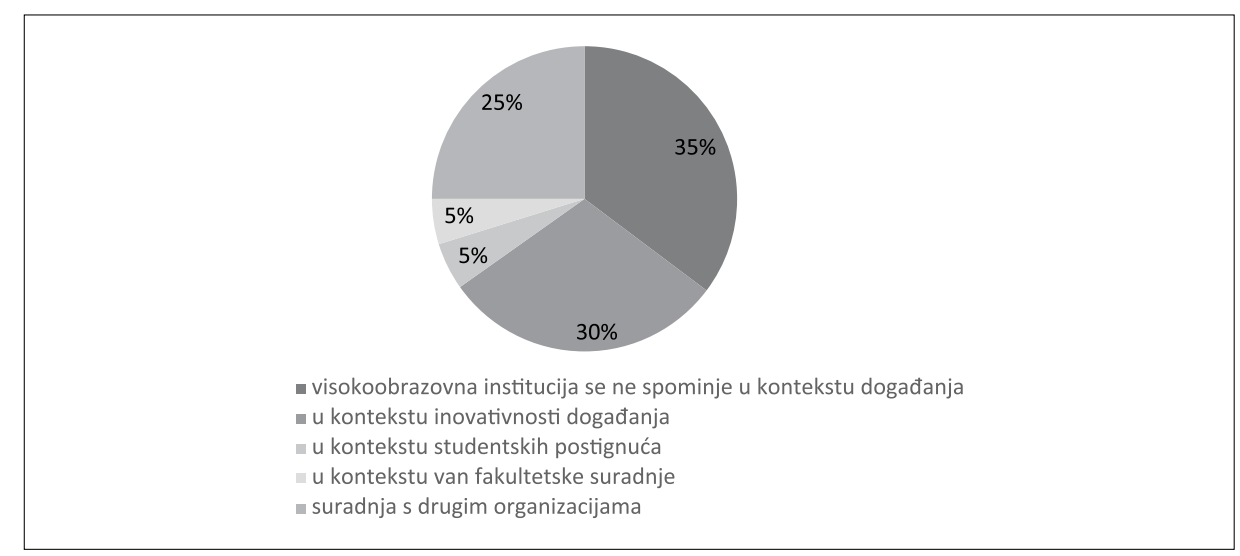

Grafikon 3. Kontekst spominjanja visokoobrazovne institucije u medijskom izvještavanju o pseduodogađaju

Graph 3. Context of mentioning a higher education institution in media coverage of a pseudo-event

Izvor: autori rada

U svima analiziranim medijskim objavama visokoobrazovna institucija ne spominje se izvan konteksta događanja. Analiza medijskih objava pokazala je prisutnost medijskih članaka o pseudodgađajima, odnosno promotivnim dosjetkama koje organiziraju odabrane visokoobrazovne institucije u Hrvatskoj, ali isto tako da je fokus izvještavanja inovativnost samog događanja, a ne inovativnost visokoobrazovne institucije.

\section{Q-metodologija}

Kao rezultat primjene Q-metodologije za Faktor 1 i Faktor 2 matematički je dobivena kompozitna „,piramida“"koja ukazuje odgovore na IP1 kojim se željelo ukazati na tip ili tematski smjer i izvedbu pseudodogađaja, a koji bi ujedno osigurali prijenos željenih poruka. Sa statističkom pouzdanošću razine $\mathrm{P}<0,01$ rezultati su prikazani u tablici 5 . 
Medij. istraž. (god. 27, br. 2) 2021. (163-187)

Tablica 2. Interpretacija izrazito pozitivnih karakteristika Faktora 1 i 2

Table 2. Interpretation of extremely positive characteristics of Factors 1 and 2

\begin{tabular}{|c|c|c|}
\hline \multicolumn{3}{|c|}{ Pozitivne preferencije - Faktor 1} \\
\hline+1 & +2 & +3 \\
\hline \multicolumn{3}{|c|}{ Oblik organiziranja } \\
\hline Uživo i online & Isključivo uživo & Isključivo uživo \\
\hline $\begin{array}{l}\text { Predavanja i interaktivne } \\
\text { radionice } \\
\text { Studentska konferencija } \\
\text { (online) }\end{array}$ & $\begin{array}{l}\text { Studentska konferencija } \\
5 \text { najkvalitetnijih projekata } \\
\text { studenata } \\
\text { Prezentacija pravih } \\
\text { studentskih poduzeća } \\
\text { Okrugli stol studentsko } \\
\text { poduzetništvo }\end{array}$ & $\begin{array}{l}\text { Predavanja } \\
\text { Interaktivne radionice } \\
\text { Nagrade -školarine/ } \\
\text { stipendije } \\
\text { Smotra } \\
\text { Interaktivne prezentacije }\end{array}$ \\
\hline \multicolumn{3}{|c|}{ Tematika } \\
\hline $\begin{array}{l}\text { Društvene mreže } \\
\text { Otkrivanje kreativnosti } \\
\text { Vježba javnog nastupa } \\
\text { Izgradnja imidža } \\
\text { Odnosi s medijima } \\
\text { Turizam } \\
5 \text { najkvalitetnijih projekata } \\
\text { studenata }\end{array}$ & $\begin{array}{l}\text { Menadžment IT sustava } \\
\text { ERP u SMEs } \\
\text { Razumijevanje IT sustava } \\
\text { Gostujući eksperti } \\
\text { Sajam ili revija za širu } \\
\text { studentsku populaciju }\end{array}$ & $\begin{array}{l}\text { Društvene mreže } \\
\text { Otkrivanje kreativnosti } \\
\text { Vježba javnog nastupa } \\
\text { Izgradnja imidža } \\
\text { Odnosi s medijima } \\
\text { Turizam } \\
\text { Uspješna poduzeća alumnija } \\
\text { Put do uspjeha }\end{array}$ \\
\hline \multicolumn{3}{|c|}{ Pozitivne preferencije - Faktor 2} \\
\hline+1 & +2 & +3 \\
\hline \multicolumn{3}{|c|}{ Oblik organiziranja } \\
\hline Uživo i online & Uživo i online & Uživo i online \\
\hline $\begin{array}{l}\text { Izložba fotografija na } \\
\text { otvorenom i u galeriji (online) } \\
\text { Izložba fotografija } \\
\text { Izložba replika/kopija (online) }\end{array}$ & $\begin{array}{l}\text { Interaktivna izložba } \\
\text { (online) } \\
\text { Studentska konferencija }\end{array}$ & Likovna izložba \\
\hline \multicolumn{3}{|c|}{ Tematika } \\
\hline $\begin{array}{l}\text { Daleka i egzotična putovanja } \\
\text { Globalno zatopljenje } \\
\text { Inovativna umjetnost } \\
\text { Najznačajniji radovi svjetskih } \\
\text { umjetnika (slike, skulpture, } \\
\text { fotografije) }\end{array}$ & $\begin{array}{l}\text { Profesionalne i amaterske } \\
\text { fotografije } \\
\text { Viđenje života u karanteni } \\
\text { Fotografije pametnim } \\
\text { telefonom } \\
\text { Inovativna umjetnost } \\
\text { ERP u SMEs } \\
\text { Eksperti govornici }\end{array}$ & $\begin{array}{l}\text { Putovanja } \\
\text { globalno zatopljenje } \\
\text { Inovativna umjetnost }\end{array}$ \\
\hline
\end{tabular}

Izvor: autori rada 
Analiza pseudodogađaja u strateškom komuniciranju visokog školstva u Hrvatskoj

Tablica 3. Interpretacija izrazito negativnih karakteristika Faktora 1 i Faktora 2

Table 3. Interpretation of extremely negative characteristics of Factor 1 and Factor 2

\begin{tabular}{|c|c|c|}
\hline \multicolumn{3}{|c|}{ Negativne preferencije - Faktor 1} \\
\hline-3 & -2 & -1 \\
\hline \multicolumn{3}{|c|}{ Oblik organiziranja } \\
\hline Isključivo online & Uživo i online & Uživo i online \\
\hline $\begin{array}{l}\text { Interaktivna izložba za } \\
\text { gledanje na pametnom } \\
\text { telefonu ili računalu } \\
\text { Izložba skulptura i kipova }\end{array}$ & $\begin{array}{l}\text { Likovna izložba } \\
\text { Izložba replika/kopija } \\
\text { radova najznačajnijih } \\
\text { svjetskih umjetnika } \\
\text { Izložba na otvorenom i u } \\
\text { galeriji }\end{array}$ & $\begin{array}{l}\text { Izložba na otvorenom i u } \\
\text { galeriji amaterskih fotografija } \\
\text { Interaktivna izložba }\end{array}$ \\
\hline \multicolumn{3}{|c|}{ Tematika } \\
\hline $\begin{array}{l}\text { Najzabavniji Tik-tok video } \\
\text { materijali (život u karanteni) } \\
\text { Viđenje života u karanteni } \\
\text { Putovanja } \\
\text { Globalno zatopljenje } \\
\text { Inovativni umjetnički oblici }\end{array}$ & $\begin{array}{l}\text { Najznačajniji radovi } \\
\text { (slike, skulpture, } \\
\text { fotografije) } \\
\text { Najzabavniji Tik-Tok } \\
\text { Video materijali (život u } \\
\text { karanteni) }\end{array}$ & $\begin{array}{l}\text { Viđenje života u karanteni } \\
\text { Najkorisniji Tik-Tok Video } \\
\text { materijali (život u karanteni) } \\
\text { Daleka ili egzotična putovanja } \\
\text { Globalno zatopljenje } \\
\text { Inovativna umjetnost }\end{array}$ \\
\hline \multicolumn{3}{|c|}{ Negativne Preferencije - Faktor 2} \\
\hline-3 & -2 & -1 \\
\hline \multicolumn{3}{|c|}{ Oblik organiziranja } \\
\hline Isključivo uživo & Uživo i online & Uživo i online \\
\hline $\begin{array}{l}\text { Izložba na otvorenom ili } \\
\text { galeriji }\end{array}$ & $\begin{array}{l}\text { Interaktivna izložba na } \\
\text { pametnom telefonu ili } \\
\text { računalu (online) } \\
\text { Smotra uspješnih } \\
\text { poduzeća alumnija }\end{array}$ & $\begin{array}{l}\text { Izložba skulptura/kipova na } \\
\text { otvorenom ili u galeriji } \\
\text { Interaktivna smotra } \\
\text { studentskih poduzeća (online) } \\
\text { Interaktivna smotra alumnija } \\
\text { (online) }\end{array}$ \\
\hline \multicolumn{3}{|c|}{ Tematika } \\
\hline $\begin{array}{l}\text { Najkorisniji Tik-Tok video } \\
\text { materijali (život u karanteni) } \\
\text { Najzabavniji Tik-Tok video } \\
\text { materijali (život u karanteni) }\end{array}$ & $\begin{array}{l}\text { Najkorisniji Tik-Tok video } \\
\text { materijali (život u } \\
\text { karanteni) } \\
\text { Najzabavniji Tik-Tok } \\
\text { video materijali (život u } \\
\text { karanteni) } \\
\text { Put do uspjeha }\end{array}$ & $\begin{array}{l}\text { Putovanja } \\
\text { globalno zatopljenje } \\
\text { Inovativni umjetnički oblici } \\
\text { Prezentacija pravih } \\
\text { studentskih poduzeća } \\
\text { Okrugli stol studentsko } \\
\text { poduzetništvo } \\
\text { Put do uspjeha }\end{array}$ \\
\hline
\end{tabular}

Izvor: autori rada 
Medij. istraž. (god. 27, br. 2) 2021. (163-187)

Vezano za negativne stoga i neželjene oblike tipa ili tematskog smjera i izvedbe pseudodogađaja koji se percipiraju kao loš način prijenosa željenih poruka, u Faktoru 1 i 2 izdvojeni su oblici i tematike prikazani u Tablici 6 sa statističkom pouzdanošću razine $\mathrm{P}<0,01$.

\section{Zaključak}

Cilj ovog rada bio je ispitati percepciju o pseudodogađajima visokoobrazovnih institucija u Hrvatskoj i to kroz dvostruki metodološki pristup: kroz analizu medijskog sadržaja i kroz abduktivni pristup donošenja zaključaka ispitanika. Ovo preliminarno istraživanje pseudodogađaja u Hrvatskoj obuhvatilo je četiri visokoobrazovne institucije i promotivne dosjetke koje se vežu za njih. Tako je u istraživanje ušla studentska konferencija u organizaciji Zagrebačke škole ekonomije i managementa, virtualna izložba fotografija pod nazivom ,theGalerija koncept“ $u$ organizaciji studenata Sveučilišta VERN', Smotra studentskih poduzeća u organizaciji Europske poslovne škole Zagreb i PRaznici na Bernaysu, odnosno edukativni projekt namijenjen maturantima i studentima preddiplomskih studija u organizaciji Edward Bernays University Collegea. Organizacija promotivnih događanja doprinosi dodatnoj vidljivosti i promociji visokoobrazovne institucije, a u Hrvatskoj i u ovom radu, to se ogleda u malom, ali dostatnom broju medijskih objava o promidžbenim dosjetkama u visokom obrazovanju. Znanstveni doprinos ovoga rada upravo se očituje u analizi malobrojnih, ali ipak medijski vidljivih pseudodogađaja koji bi se na temelju rezultata ovog istraživanja mogli intenzivnije implementirati u komunikacijske strategije visokih učilišta, o čemu svjedoče i rezultati q-metodologije koja je detaljno ispitala mišljenja 40 ispitanika o analiziranim pseudodogađajima. Rezultati istraživanja, osim što otvaraju prostor za dodatno istraživanje ovog slabo analiziranog alata u odnosima s javnošću, svojevrsni su poticaj komunikacijskim praktičarima za aktivnijom upotrebom pseudodogađaja u oblikovanju i provedbi komunikacijskih strategija. Analiza sadržaja medijskih objava promotivnih događaja odabranih visokoobrazovnih institucija u Hrvatskoj pokazala je kako izvještavanje o pseudodogađaju ne doprinosi medijskom izvještavanju o visokoobrazovnoj instituciji jer mediji pretežno izvještavaju o samom događaju, a ne toliko o visokoobrazovnoj instituciji. Isto tako, većina medijskih objava usmjerena je na promoviranje pseudodogađaja, a ne visokoobrazovne institucije. Visokoobrazovna institucija u većini analiziranih objava spominje se samo u kontekstu događanja te sve medijske objave u svom glavnom fokusu izvještavaju o pseudodogađaju, a ne o visokoobrazovnoj instituciji. Analiza je pokazala da je vrijednosna orijentacija članaka prema pseudodogađaju pretežno ili pozitivna ili neutralna, što potvrđuje pozitivan promidžbeni doprinos koji imaju promidžbene dosjetke na medijsko izvještavanje. 
Analiza pseudodogađaja u strateškom komuniciranju visokog školstva u Hrvatskoj

Nadalje, s obzirom na to da je ovo istraživanje prvo istraživanje o pseudodogađaju u Hrvatskoj, a posebno o pseudodogađajima u visokom obrazovanju, time ujedno predstavlja i eksplorativno istraživanje. Da bi se mogli donijeti relevantniji zaključci o tome kako mediji izvještavaju o pseudodogađajima, odnosno o promotivnim dosjetkama u visokom obrazovanju, potrebno je uključiti više takvih dosjetki s različitih visokoobrazovnih institucija u Hrvatskoj te utvrditi postoji li razlika u organizaciji ovakvih događanja između privatnih i javnih visokoobrazovnih institucija. Rezultati istraživanja pokazali su dva statistički relevantna faktora, s time da dominantan Faktor 1 ukazuje na važnost organiziranja pseudodogađaja uživo s tematikom u smjeru primarne djelatnosti visokog učilišta i demonstracijom očekivanih ishoda procesa poučavanja (predavanja, interaktivne radionice, smotra, prezentacije). Faktor 2 ukazuje da i dosjetke u smjeru (umjetničkih), prvenstveno likovnih izložbi s relevantnim temama, ima smisla komunicirati prema javnosti i povezivati s visokoškolskim učilištima. „Stršeće“ negativne preferencije za oba faktora zaslužuju posebnu pažnju pri potencijalnoj daljnjoj analizi jer se zasigurno i takvi tipovi dosjetki mogu dodatno tematski modelirati kako bi uspješno prenijeli željenu poruku do ciljanih skupina.

\section{LITERATURA}

Agencija za znanost i visoko obrazovanje (2021a) Visoka učilišta u Republici Hrvatskoj, https://www.azvo.hr/hr/vvivs/43-visoko-obrazovanje/603-visoka-uilita-u-republici-hrvatskoj (26. 4. 2021.).

Agencija za znanost i visoko obrazovanje (2021b) Visoka učilišta u Republici Hrvatskoj, https://www.azvo.hr/hr/visoko-obrazovanje/visoka-ucilista (21. 8. 2021.).

Argenti, P. A., Howell, R. A. i K. A. Beck (2005) “The Strategic Communication Imperative", MIT Sloan Management Review (SMR), 46 (3), 83-89.

Babiarz, M. i D. Kukla (2012) "In Communicative Circle Towards The Future Of Education", Informatologia, 45 (4), 328-332.

Babić, Z., Matković, T. i V. Šošić (2006) "Strukturne promjene visokog obrazovanja i ishodi na tržištu rada", Privredna kretanja i ekonomska politika, 16 (108), 26-65.

Banasick, S. (2019) Ken-Q Analysis, https://shawnbanasick.github.io/ken-q-analysis/ (8. 5. 2021.).

Bernays, E. L. (1952) Public Relations. University of Oklahoma Press Norman, https://books.google.hr/books? id $=0 \mathrm{NpSb} 5 \mathrm{nmn} 5 \mathrm{sC} \&$ printsec $=$ frontcover $\& \mathrm{hl}=\mathrm{h}$ $\mathrm{r} \# \mathrm{v}=$ onepage $\& \mathrm{q} \& \mathrm{f}=$ false $(25.4 .2021$.). 
Bernays.hr (2021) Praznici na Bernaysu, https://www.bernays.hr/Home/Page/hrHR?name=praznici (27. 4. 2021.).

Betterevaluation.org (2014) Q-methodology, https://www.betterevaluation.org/en/ evaluation-options/qmethodology (27. 4. 2021.).

Blaire Dawson, M. (2020) In PR, "stunt" should not be a dirty word, https://www. prweek.com/article/1697289/pr-stunt-not-dirty-word (26. 4. 2021.).

Boorstin, D. (2006) "From News Gathering to News Making: a Flood of PseudoEvents", Journalism: The democratic Craft, 80-98.

Buble, M. i dr. (2005) Strateški menadžment. Zagreb: Sinergija.

D’agostino, R. i H. K. Russell (2005) "Scree Test”. Encyclopedia of Biostatistics, 8-Volume Set, 2nd ed, Willey Online Library.

Ebus.hr (2020) 10. Smotra studentskih poduzeća i studentskih poduzetničkih inkubatora $i$ 2. Forum poslovnih mogućnosti za samozapošljavanje, http://ebus. $\mathrm{hr} / 2020 / 01 / 18 / 10$-smotra-studentskih-poduzeca-i-studentskih-poduzetnickihinkubatora-i-2-forum-poslovnih-mogucnosti-za-samozaposljavanje/ (27. 4. 2021.).

Elezović, A. (2012) "O čemu pišu novine? Analiza sadržaja novinskih naslovnica (siječanj - lipanj 2011.)”, Medijska istraživanja, 18 (1), 61-88.

Gajić, G. J. (2010) Marketing strategija u visokom obrazovanju (doktorska disertacija). Beograd: Univerzitet Singidunum.

Halmi, A. (1996) Kvalitativna metodologija u društvenim znanostima. Samobor: A. G. Matoš d.d.

Jongbloed, B., Enders, J. i C. Salerno (2008) "Higher education and its communities: Interconnections, interdependencies and a research agenda", High Educ, 56, 303-324. doi.org/10.1007/s10734-008-9128-2.

Krivačić, D. (2010) 'Poslovna strategija veleučilišta i visokih škola”, Poslovna izvrsnost, 4 (2), 121-131.

Leigh, R. (2017) My slides from PR Fest 2017: “PR stunts - a relic of a bygone age, or a useful PR tactic?, https://www.radioactivepr.com/pr-fest-2017-a-pr-agency-look-at-pr-stunts/ (26. 4. 2021.).

Marjanović, B. i M: Učeta (2021) "Segementacija tržišta visokog obrazovanja", Zbornik radova Veleučilišta u Šibeniku, 15 (1-2), 151-169. doi.org/10.51650/ ezrvs.15.1-2.10.

Marshall, G. C. (2003) A q-methodology evaluation of visions of sustainable development, http://ro.ecu.edu.au/theses/1495 (27. 4. 2021.).

Milas, G. (2005) Istraživačke metode u psihologiji i drugim društvenim znanostima. Zagreb: Slap.

Miletić, J. (2020) "Uloga marketinga u upravljanju odgojnoobrazovnom ustanovom”, Školski vjesnik, 69 (1), 261-276. doi.org/10.38003/sv.69.1.7. 
Analiza pseudodogađaja u strateškom komuniciranju visokog školstva u Hrvatskoj

Poljičak, I. (2014) “Analiza sadržaja novinskih članaka o povijesnoj jezgri Šibenika u 'Šibenskom tjedniku'”. Zbornik radova Veleučilišta u Šibeniku, 1 (2), 7-18.

Q Methodology (2021) Q Methodology for the Scientific Study of Human Subjectivity, https://qmethod.org/resources/software/ (8. 5. 2021.).

Renko, N. (2009) Strategije marketinga. Zagreb: Naklada Ljevak d.o.o.

Rogers, W. S. (2011) Social Psychology. Berkshire: Open University Press.

Rupčić, N. (2011) "Izgradnja učećih organizacija kao modalitet izgradnje učećega društva", Praktični menadžment, 2 (2), 20-27.

Shank, G. (1998) "The extraordinary ordinary powers of abductive reasoning", Theory and Psychology, 8 (6).

Smith, R. (2005) Strategic Planning for Public Relations. New Jersey: Lawrence Erlbaum Associates.

Stanišić, D., Puška, A. i A. Maksimović (2015) "Analiza primjene promotivnih strategija na visokoškolskim ustanovama, u uslovima ekonomizacije visokog obrazovanja, u Bosni i Hercegovini", Tranzicija, 17 (35), 37-56.

Steyn, B. (2003) "From Strategy to Corporate Communication Strategy: A Conceptualisation", Journal of Communication Management, 8 (2), 168-183.

Sugget, P. (2019) 10 Advertising and PR Stunt Ideas to Get Your Brand Noticed, https://www.thebalancecareers.com/advertising-pr-stunts-to-get-your-brand-noticed-4139850 (23. 4. 2021.).

Valić Nedeljković, D. (2007) "Pseudodogađaj ili dvosmislena istina", MediAnali, 1 (2), 67-86.

Vern.hr (2020) VERN'ovi studenti vas pozivaju - Prošetajte prvom interaktivnom virtualnom izložbom u Hrvatskoj, https://vern.hr/dogadanja/vernovi-studentivas-pozivaju-prosetajte-prvom-interaktivnom-virtualnom-izlozbom-u-hrvatskoj/ (27. 4. 2021.)

Vidulin-Orbanić, S. (2007) Društvo koje uči: Povijesno-društveni aspekti obrazovanja. Pula: Filozofski fakultet.

Vlada Republike Hrvatske (2014) Strategija obrazovanja, znanosti i tehnologije.

Wertheimer-Baletić, A. (2017) "Demografski procesi u Hrvatskoj i u zapadnoeuropskim zemljama - razlike, sličnosti i specifičnosti”, Rad Hrvatske akademije znanosti $i$ umjetnosti. Razred za društvene znanosti, (529=52), 1-28. doi. org $/ 10.21857 / \mathrm{m} 16 \mathrm{wjcp} 4 \mathrm{v} 9$.

Zagrebačka škola ekonomije i managementa (ZSEM) (2021) Management informacijskih sustava, https:/www.zsem.hr/clanak/studentska-konferencija-management-informacijskih-sustava/ (27. 4. 2021.). 


\title{
Analysis of Pseudo-events in Strategic Communication of Higher Education in Croatia
}

\author{
Lucijano Jakšić \\ Krešimir Dabo \\ Marija Volarević
}

\section{SUMMARY}

Communication with the target public and the promotion of products and services in recent years have transformed from opportunity to necessity. This refers to the for-profit and non-profit sector of the economy. Digitization and popularization of social media, the need for publicity and reach to end users and consumers, and monitoring of competition are becoming the primary challenges of strategic communication. Emphasizing certain elements of business in a new and innovative way enables attracting public attention and achieving wider publicity. The tool of public relations, the so-called promotional joke, pseudoevent or PR stunt. New media, and especially platforms for social networking, give such content a great reach, significant popularity, but perhaps the most important thing - a great return on investment. This trend does not bypass higher education either. A review of the research found that elements of pseudoevents are already used in the communication of world-famous higher education systems, and all are based on collective and team activities and joint creation of content that is shared and becomes part of media reporting. The aim of this paper is to examine the public perception related to selected pseudo-events in Croatian private higher education. The research is based on a sample of targeted publics of private higher education institutions in Croatia and an examination of the perception of the content and messages of pseudo-events that promote higher education institutions. The paper uses a double methodological approach in order to achieve the set goal. The method of content analysis examined publicly available media content on selected private higher education institutions and conclusions were drawn on the focus of media publication, value orientation towards pseudo-events and towards higher education institutions. The $Q$ method was used to examine the perception of the target public regarding the promotional activities of higher education in Croatia, specifically selected 
pseudo-events at their higher education institution. Private higher education in Croatia is characterized by high competitiveness. Related to this is the need to select adequate communication activities. The contribution of this paper is in the exploratory approach to the phenomenon of pseudo-events in higher education in Croatia and the detection of promotional elements of selected higher education institutions.

Keywords: public relations, promotion, pseudo-event, strategic communication, higher education 